Article

\title{
Phytotoxic Activity of Metabolites Isolated from Rutstroemia sp.n., the Causal Agent of Bleach Blonde Syndrome on Cheatgrass (Bromus tectorum)
}

\author{
Marco Masi ${ }^{1}$ (D), Susan Meyer ${ }^{2}$, Marcin Górecki ${ }^{3,4}$, Gennaro Pescitelli $^{3}{ }^{(0)}$, Suzette Clement ${ }^{2}$, \\ Alessio Cimmino ${ }^{1}$ (D) and Antonio Evidente ${ }^{1, *}$ \\ 1 Dipartimento di Scienze Chimiche, Università di Napoli “Federico II", Complesso Universitario Monte S. \\ Angelo, Via Cintia 4, 80126 Napoli, Italy; marco.masi@unina.it (M.M.); alessio.cimmino@unina.it (A.C.) \\ 2 US Forest Service Rocky Mountain Research Station, Shrub Sciences Laboratory, 735 North 500 East, Provo, \\ UT 84606, USA; semeyer@xmission.com (S.M.); sclement@fs.fed.us (S.C.) \\ 3 Dipartimento di Chimica e Chimica Industriale, Università di Pisa, Via Moruzzi 13, 56124 Pisa, Italy; \\ marcin.gorecki@icho.edu.pl (M.G.); gennaro.pescitelli@unipi.it (G.P.) \\ 4 Institute of Organic Chemistry, Polish Academy of Sciences, ul. Kasprzaka 44/52, 01-224 Warsaw, Poland \\ * Correspondence: evidente@unina.it; Tel.: +39-081-253-9178
}

Received: 25 June 2018; Accepted: 12 July 2018; Published: 16 July 2018

\begin{abstract}
A fungal pathogen soon to be described as Rutstroemia capillus-albis (Rutstroemiaceae, Helotiales, Leotiomycetes) has been identified as the causal agent of 'bleach blonde syndrome' on the invasive annual grass weed Bromus tectorum (cheatgrass) in western North America. This apparently common but previously undescribed disease causes premature senescence and sterility, but does not affect seed germination or seedling emergence and growth. This study investigated whether the new species produces phytotoxins that could be implicated in pathogenesis. The compounds 9-O-methylfusarubin, 9-O-methylbostrycoidin, 5-O-methylnectriafurone, trans-methyl- $p$-coumarate and terpestacin were isolated from the solid culture of this fungus. The undescribed absolute stereochemistry at C-3 of 9-O-methylfusarubin and at C-1' of 5-O-methylnectriafurone were assigned by applying electronic and vibrational circular dichroism (ECD and VCD) combined with computational methods and the advanced Mosher's method, respectively. The first three listed compounds are naphtoquinone pigments, while terpestacin is a sesterterpene, and trans-methyl-p-coumarate could be the product of an unusual fungal phenylpropanoid biosynthesis pathway. In a juvenile plant immersion bioassay, both 9-O-methylfusarubin and terpestacin proved to be highly toxic at $10^{-4} \mathrm{M}$, causing wilting and plant death within 10 days. This finding suggests that these two compounds could play a role in pathogenesis on B. tectorum.
\end{abstract}

Keywords: Bromus tectorum; Rutstroemia sp.n.; phytotoxic metabolites; immersion bioassay; 9-O-methylfusarubin and terpestacin

\section{Introduction}

The invasive winter annual grass weed Bromus tectorum (cheatgrass) is dramatically altering the semi-arid shrubland ecosystems in the western USA. Increasing wildfire frequency and intensity has resulted in near-monocultures of this weed over very large areas [1,2]. A frequent occurrence in some areas heavily invaded by $B$. tectorum is periodic 'cheatgrass die-off' or complete stand failure. This poorly understood phenomenon is apparently caused by a complex interaction among multiple soilborne fungal pathogens [3]. To help elucidate the 'die-off' phenomenon, the ability of some of these pathogens to produce phytotoxins was investigated. From the solid cultures of Pyrenophora semeniperda (Brittlebank and Adams) Shoemaker [4,5], a large quantity of cytotoxic cytochalasin B was isolated, 
along with smaller quantities of related cytochalasans [6]. Successively, the known abscisic acid was also isolated together with three new phytotoxic sesquiterpenoids (named pyrenophoric acid and pyrenophoric acids B and C) from the same cultures [7,8]. In a cheatgrass seedling bioassay, all these compounds were able to induce growth suppression of both radicles and coleoptiles [6-8]. From the potato dextrose broth culture of $P$. semeniperda, a new $\gamma$-lactam, named spirostaphylotrichin $\mathrm{W}$, was isolated together with some known spirostaphylotrichins. Some of these compounds caused necrosis in leaf puncture bioassays while having little effect on cheatgrass seedlings $[9,10]$.

Recently, acuminatopyrone, blumenol A, chlamydosporol, isochlamydosporol, ergosterol and 4-hydroxybenzaldehyde were isolated from a Fusarium strain belonging to the Fusarium tricinctum species complex grown on cheatgrass seed culture. In a B. tectorum seedling bioassay, 4-hydroxybenzaldehyde proved to be the most active compound [11].

During investigation of the die-off phenomenon, epidemic levels of a previously undescribed disease on B. tectorum were noted in some years. This disease, named the 'bleach blonde syndrome', causes premature senescence, sterility, and death at the heading stage. It is not a direct cause of stand failure, but may be a factor that predisposes a B. tectorum stand to emergence failure in a subsequent year [3]. Pathogenicity tests combined with molecular genetic analysis demonstrated that the causal agent of this disease is a new fungus of the genus Rutstroemia related to the dollar spot pathogen of turf ('Sclerotinia' homoeocarpa). This fungus has been described as Rutstroemia capillus-albis (Rutstroemiaceae, Helotiales, Leotiomycetes) [12].

As secondary metabolite production in the genus Rutstroemia has never been examined and is poorly studied in the Leotiomycetes in general, a study was undertaken to determine whether secondary metabolites that could play a role in pathogenesis were produced by this fungus. Furthermore, their potential application as natural herbicides was also evaluated for the biological control of cheatgrass.

This paper reports the isolation of five secondary metabolites produced by the newly described plant pathogen R. capillus-albis, as well as their phytotoxic activity against B. tectorum.

\section{Material and Methods}

\subsection{General Experimental Procedures}

Optical rotations were measured in $\mathrm{MeOH}$ on a Jasco P-1010 digital polarimeter (Jasco, Tokyo, Japan). IR spectra were recorded as deposit glass film on a Thermo Nicolet 5700 FT-IR spectrometer (Madison, WI, USA). UV spectra were measured in $\mathrm{MeCN}$ and $\mathrm{MeOH}$ on a Jasco V-530 spectrophotometer (Jasco, Tokyo, Japan). ECD spectra were recorded on a Jasco J-715 (Jasco Co., Tokyo, Japan) spectropolarimeter in $\mathrm{MeCN}$ in the range of 200 to $700 \mathrm{~nm}$ with the following conditions: scanning speed of $100 \mathrm{~nm} \mathrm{~min}{ }^{-1}$, step size of $0.2 \mathrm{~nm}$, bandwidth of $2 \mathrm{~nm}$, response time of $0.5 \mathrm{~s}$, and accumulation of 16 scans. The spectra were background-corrected using the spectra of MeCN recorded under the same conditions. IR/VCD spectra were recorded on a Jasco FVS-6000 VCD spectrometer (Jasco, Tokyo, Japan) using a resolution of $4 \mathrm{~cm}^{-1}$ in the range of 2000 to $900 \mathrm{~cm}^{-1}$ in $\mathrm{CD}_{3} \mathrm{OD}$ solutions for $2 \mathrm{~h}$ (4000 accumulations). The spectra were background-corrected using spectra of $\mathrm{CD}_{3} \mathrm{OD}$ recorded under the same conditions. ${ }^{1} \mathrm{H}$ - and ${ }^{13} \mathrm{C}-\mathrm{NMR}$ spectra were recorded at 500 and 400 , and at 125 and $100 \mathrm{MHz}$, respectively, in $\mathrm{CDCl}_{3}$ on Varian (Varian, Palo Alto, USA) and Bruker (Bruker, Karlsruhe, Germany) spectrometers. The same solvent was used as internal standard. Carbon multiplicities were determined by DEPT (Distortionless Enhancement by Polarization Transfer) spectra [13]. Band-selective ROESY (Rotating-frame nuclear Overhauser Effect correlation Spectroscopy) experiments were performed with the following parameters: mixing time, 200-500 ms; band-selective pulse, 5.74 ms; f1 pulse band-width, $700 \mathrm{~Hz}$. HRESIMS (High Resolution ElectroSpray Ionization Mass Spectroscopy) and ESIMS (ElectroSpray Ionization Mass Spectroscopy), spectra were recorded on an Agilent 6120 Quadrupole LC/MS instrument (Agilent Technologies, Milan, Italy), respectively. Analytical and preparative TLC (Thin Layer Chromatography) were performed on 
silica gel (Kieselgel 60, $\mathrm{F}_{254}, 0.25$ and $0.5 \mathrm{~mm}$ respectively) and on reversed phase (Merck, Kieselgel $60 \mathrm{RP}-18, \mathrm{~F}_{254}, 0.20 \mathrm{~mm}$ ) plates. The spots were visualized by exposure to UV radiation $(253 \mathrm{~nm})$, or iodine vapour, or by spraying first with $10 \% \mathrm{H}_{2} \mathrm{SO}_{4}$ in $\mathrm{MeOH}$ and then with $5 \%$ phosphomolybdic acid in $\mathrm{EtOH}$, followed by heating at $110{ }^{\circ} \mathrm{C}$ for $10 \mathrm{~min}$. Column chromatography was performed using silica gel (Merck, Kieselgel 60, 0.06-0.200 mm).

\subsection{Fungal Strain}

The R. capillus-albis strain used in this study was obtained from a diseased B. tectorum plant collected by J.F. Pearce at the Whiterocks study site in Skull Valley, Tooele County, Utah, USA $\left(40.329381^{\circ}-112.778614^{\circ}, 1447 \mathrm{~m}\right)$ in May 2012.

\subsection{Extraction and Purification of R. capillus-albis Secondary Metabolites}

The fungus was produced in solid culture by inoculating autoclaved oat chaff [13] with a 5-day-old liquid culture (potato dextrose broth, $22^{\circ} \mathrm{C}$ ) and incubating under sterile conditions in aluminium pans with plastic covers for three weeks. The culture was then spread out to air-dry in a laminar flow hood for at least several weeks prior to extraction. The dried material (1000 g) was minced using a laboratory mill and extracted with $2 \mathrm{~L}$ of $\mathrm{MeOH}-\mathrm{H}_{2} \mathrm{O}(1 \% \mathrm{NaCl})(1: 1)$. The mixture was centrifuged for $1 \mathrm{~h}$ at $7000 \mathrm{rpm}$ and the supernatant was pooled and defatted by $n$-hexane $(2 \times 1 \mathrm{~L})$. The resulting aqueous phase was extracted $(3 \times 1 \mathrm{~L})$ with $\mathrm{CH}_{2} \mathrm{Cl}_{2}$. The combined organic extracts were dehydrated (by $\mathrm{Na}_{2} \mathrm{SO}_{4}$ ) and evaporated under reduced pressure to yield a brown solid residue (1.42 g). This latter was fractioned by column chromatography on silica gel eluted with $\mathrm{CHCl}_{3}-i-\mathrm{PrOH}$ (95:5). Twelve fraction groups were collected on the basis of similar TLC profiles. The residue $(26.7 \mathrm{mg})$ of the third fraction was further purified by TLC eluted with $\mathrm{CHCl}_{3}-i-\mathrm{PrOH}$ (99:1) yielding an amorphous solid, identified as reported below as the trans-methyl-p-coumarate $\left(4,8.3 \mathrm{mg}, \mathrm{R}_{f} 0.13\right)$. The residue $(48.1 \mathrm{mg})$ of the fifth fraction was purified by TLC successively eluted three times with petroleum ether- $\mathrm{Me}_{2} \mathrm{CO}(7: 3)$ affording a yellow amorphous solid and a red powder, identified as reported below as 8-O-methylnectriafurone $\left(3,5.9 \mathrm{mg}, \mathrm{R}_{f} 0.26\right)$ and 9-O-methylbostrycoidin $\left(\mathbf{2}, 12.2 \mathrm{mg}, \mathrm{R}_{f} 0.45\right)$, respectively. The residue $(83.8 \mathrm{mg})$ of the sixth fraction was further purified by column chromatography on silica gel eluted with $\mathrm{CHCl}_{3}-\mathrm{MeOH}$ (95:5) affording an additional amount of $\mathbf{2}$ (10.0 $\mathrm{mg}$ for a total of $22.2 \mathrm{mg}$ ) and the main metabolite as an amorphous red solid, identified as reported below as 9-O-methylfusarubin $\left(\mathbf{1}, 43.7 \mathrm{mg}, \mathrm{R}_{f} 0.48\right)$. The residue $(41.3 \mathrm{mg})$ of the eighth fraction was further purified by preparative TLC eluted with EtOAc-MeOH- $\mathrm{H}_{2} \mathrm{O}$ (90:7:3), followed by a second purification using petroleum ether- $\mathrm{Me}_{2} \mathrm{CO}$ (7:3) to afford an amorphous solid, identified as reported below as terpestacin $\left(5,7.5 \mathrm{mg}, \mathrm{R}_{f} 0.38\right)$.

\subsection{Compound Characterization}

9-O-Methylfusarubin (1): Its ${ }^{1} \mathrm{H}$ - and ${ }^{13} \mathrm{C}-\mathrm{NMR}$ spectra were very similar to those already reported in literature [14,15]; HRESIMS (+) $m / z 321.0979[\mathrm{M}+\mathrm{H}]^{+}$(calcd. for $\mathrm{C}_{16} \mathrm{H}_{17} \mathrm{O}_{7}, 321.0974$ ).

9-O-Methylbostrycoidin (2): Its ${ }^{1} \mathrm{H}$ - and ${ }^{13} \mathrm{C}-\mathrm{NMR}$ spectra were very similar to those already reported in literature [14,16]; HRESIMS (+) $m / z: 300.0880[\mathrm{M}+\mathrm{H}]^{+}$(calcd for $\mathrm{C}_{16} \mathrm{H}_{14} \mathrm{NO}_{5}$ 300.0872).

5-O-Methylnectriafurone (3): Its ${ }^{1} \mathrm{H}$ - and ${ }^{13} \mathrm{C}-\mathrm{NMR}$ spectra were very similar to those already reported in literature [14,17]; HRESIMS (+) $m / z: 319.0803[\mathrm{M}+\mathrm{H}]^{+}$(calcd. for $\mathrm{C}_{16} \mathrm{H}_{15} \mathrm{O}_{7}, 319.0818$ ).

trans-Methyl-p-coumarate (4): Its ${ }^{1} \mathrm{H}$ - and ${ }^{13} \mathrm{C}-\mathrm{NMR}$ spectra were very similar to those already reported in literature [18]; HRESIMS (+) m/z: $179.0711[\mathrm{M}+\mathrm{H}]^{+}$(calcd. for $\mathrm{C}_{10} \mathrm{H}_{11} \mathrm{O}_{3}, 179.0708$ ).

Terpestacin (5): $[\alpha]_{\mathrm{D}}^{25}$ : $-17.7\left(c=0.4, \mathrm{CHCl}_{3}\right)$; Its ${ }^{1} \mathrm{H}$ - and ${ }^{13} \mathrm{C}$-NMR spectra were very similar to those already reported in literature [19]; HRESIMS (+) $m / z: 425.2743[\mathrm{M}+\mathrm{Na}]^{+}$(calcd. for $\mathrm{C}_{25} \mathrm{H}_{38} \mathrm{NaO}_{4}$, 425.2750). 
1'-O-(S)- $\alpha$-Methoxy- $\alpha$-trifluoromethyl- $\alpha$-phenylacetate (MTPA) ester of 5-O-Me nectriafurone (6): $(R)-(-)$-MPTA-Cl $(5 \mu \mathrm{L})$ was added to $3(0.5 \mathrm{mg})$ dissolved in dry pyridine $(20 \mu \mathrm{L})$. The mixture was kept at room temperature for $24 \mathrm{~h}$ and then the reaction was stopped by adding $\mathrm{MeOH}$ and the azeotrope formed by addition of $\mathrm{C}_{6} \mathrm{H}_{6}$ was evaporated under reduced pressure. The residue $(0.8 \mathrm{mg})$ was purified by preparative TLC, eluted with $\mathrm{CHCl}_{3}-i-\mathrm{PrOH}$ (98:2), yielding 6 as a yellow amorphous solid $\left(R_{f} 0.43,0.6 \mathrm{mg}\right)$. It had: IR $v_{\max } 3270,1732,1637,1554,1453,1376,1250 \mathrm{~cm}^{-1}$; UV $\lambda_{\max } \mathrm{nm}(\log$ ع) 444 (4.01), 318 (3.92), 261 (shoulder, 4.16), 237 (4.30); ${ }^{1} \mathrm{H}-\mathrm{NMR}$ spectrum see Table 1; HRESIMS (+) $m / z 535.1220[\mathrm{M}+\mathrm{H}]^{+}$(calcd. for $\mathrm{C}_{26} \mathrm{H}_{22} \mathrm{~F}_{3} \mathrm{O}_{9}, 535.1216$ ).

$1^{\prime}-O-(R)-\alpha-M e t h o x y-\alpha$-trifluoromethyl- $\alpha$-phenylacetate (MTPA) ester of 5-O-Me nectriafurone (7): $(S)-(+)-M P T A-C l(5 \mu \mathrm{L})$ was added to $3(0.5 \mathrm{mg})$ dissolved in dry pyridine $(20 \mu \mathrm{L})$. The reaction was carried out under the same conditions used for preparing 6 from 3 . The purification of the crude residue $(0.7 \mathrm{mg})$ by preparative TLC eluted with $\mathrm{CHCl}_{3}-i-\mathrm{PrOH}(98: 2)$, to give 7 as a yellow amorphous solid $\left(R_{f} 0.43,0.5 \mathrm{mg}\right)$. It had: IR $v_{\max } 3272,1733,1642,1556,1462,1374,1251 \mathrm{~cm}^{-1}$; UV $\lambda_{\max } \mathrm{nm}(\log$ ع) 443 (4.00), 316 (3.89), 258 (shoulder, 4.14), 238 (4.28); ${ }^{1} \mathrm{H}$-NMR spectrum see Table 1; HRESIMS (+) $m / z 535.1219[\mathrm{M}+\mathrm{H}]^{+}$(calcd. for $\mathrm{C}_{26} \mathrm{H}_{22} \mathrm{~F}_{3} \mathrm{O}_{9}, 535.1216$ ).

\subsection{Computational Section}

Molecular mechanics and preliminary Density Functional Theory (DFT) calculations were run with Spartan'16 (Wavenfunction, Irvine, CA, USA, 2016) with default parameters, default grids and convergence criteria; DFT and Time-Dependent DFT (TDDFT) calculations were run with Gaussian'16 (Gaussian Inc.: Wallingford, CT, USA) [20] with default grids and convergence criteria. Conformational analyses were run with the Monte Carlo procedure implemented in Spartan'16 using Merck molecular force field (MMFF). All structures obtained thereof were optimized with DFT at $\omega B$ 97X-D/6-31G(d) level in vacuo, and reoptimized at the $\omega B 97 X-D / 6-311+G(d, p)$ level in vacuo. Final optimizations were run at the $\omega \mathrm{B} 97 \mathrm{X}-\mathrm{D} / 6-311+\mathrm{G}(\mathrm{d}, \mathrm{p})$ level including the polarizable continuum model $(\mathrm{PCM})$ for $\mathrm{MeCN}$ or $\mathrm{MeOH}$ in its Integral Equation Formalism (IEF) formulation. The above procedure afforded 3 minima for compound 1, the most stable of which had a population of $>93 \%$ in both solvents. Frequency calculations were run at the $\omega B 97 X-D / 6-311+G(d, p) / P C M$ level of theory. TDDFT calculations were run with several functionals (B3LYP, CAM-B3LYP, $\omega B$ 97X-D, M06-2X, PBE0 and BH\&HLYP) and def2-TZVP basis set, and included PCM for MeCN. Average ECD spectra were computed by weighting ECD and VCD spectra (calculated for each conformer) with Boltzmann factors at $300 \mathrm{~K}$ estimated from DFT internal energies. ECD and VCD spectra were plotted using the program SpecDis [21,22], applying the dipole-length formalism for rotational strengths; the difference with dipole-velocity values was negligible. Similarity factors were also estimated with SpecDis.

\subsection{Bioassays}

The seedling radicle/coleoptile bioassay was conducted using nondormant $B$. tectorum seeds. Compounds were first dissolved in DMSO, which was then diluted to a $2 \%$ aqueous solution to obtain each compound at a concentration of $10^{-4} \mathrm{M}$. For each compound, $250 \mu \mathrm{L}$ of the solution was pipetted into each of three $3.5 \mathrm{~cm}$ Petri dishes onto the surface of one filter paper. Seeds were incubated in $2 \%$ DMSO in the control treatment. Four B. tectorum seeds were arranged onto the surface of each filter paper in a pattern that made it possible to track individual seeds. Petri dishes were sealed with parafilm to retard moisture loss and incubated at $20^{\circ} \mathrm{C}$ with a $12: 12 \mathrm{~h}$ photoperiod. Germination was scored each day, and germination day was tracked individually for each seed. Five days after germination for each seed, the coleoptile and radicle lengths of each seedling were measured and recorded using electronic calipers. All seeds germinated within 14 days. Petri dish was treated as the blocking variable with individual seeds as replicates within blocks in mixed model analysis of variance (ANOVA) using SAS Proc Mixed (Statistical Analysis Institute, Boca Raton, FL, USA) with compound 
as the class variable. Response variables (radicle length and coleoptile length) were log-transformed to meet the assumptions of ANOVA prior to analysis.

For the juvenile plant immersion bioassay, plants were grown from seeds to the two-leaf stage in solution culture with a complete nutrient solution. Test compounds were first dissolved in $\mathrm{MeOH}$, and then diluted with $\mathrm{H}_{2} \mathrm{O}$ to $2 \% \mathrm{MeOH}\left(10^{-4} \mathrm{M}\right.$ concentration of each compound). For each of three replicates of each compound, $2 \mathrm{~mL}$ of test solution were pipetted into a small vial. Juvenile plants were then transferred in groups of three to each vial for a total of nine seedlings per treatment. Roots were immersed in the test solution, while shoots were not immersed. The $2 \% \mathrm{MeOH}$ solvent was used as the control. Vials were placed under fluorescent lights at room temperature $\left(22^{\circ} \mathrm{C}\right)$ and monitored for signs of toxicity over a period from 4-10 days. Ten-day data are reported. The individual plants were scored on a semi-quantitative scale from 0 (no visible damage) to 5 (complete mortality). The ordinal damage scale was approximately linear and was treated as a quantitative response variable in ANOVA using a mixed model procedure for a randomized block design, with vial as the blocking random variable and individual seedlings as replicates within blocks, as described earlier for the radicle/coleoptile elongation test.

\section{Results and Discussion}

The solid culture of R. capillus-albis was extracted as reported in detail in the Experimental section. The $\mathrm{CH}_{2} \mathrm{Cl}_{2}$ organic extract showed strong phytotoxic activity when tested against $B$. tectorum using an immersion bioassay (Figure 1). Thus, it was purified using a systematic bioassay-guided fractionation (Scheme S1) yielding five pure compounds (1-5, Figure 2).

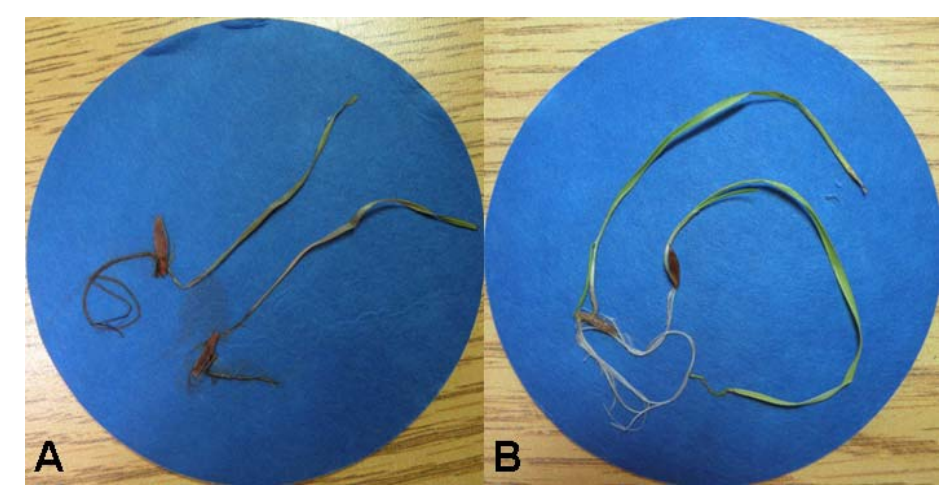

Figure 1. Juvenile plant immersion test on Bromus tectorum: (A) cheatgrass plants tested with $\mathrm{CH}_{2} \mathrm{Cl}_{2}$ organic extract at $2 \mathrm{mg} / \mathrm{mL}$ after 10 days; (B) control.

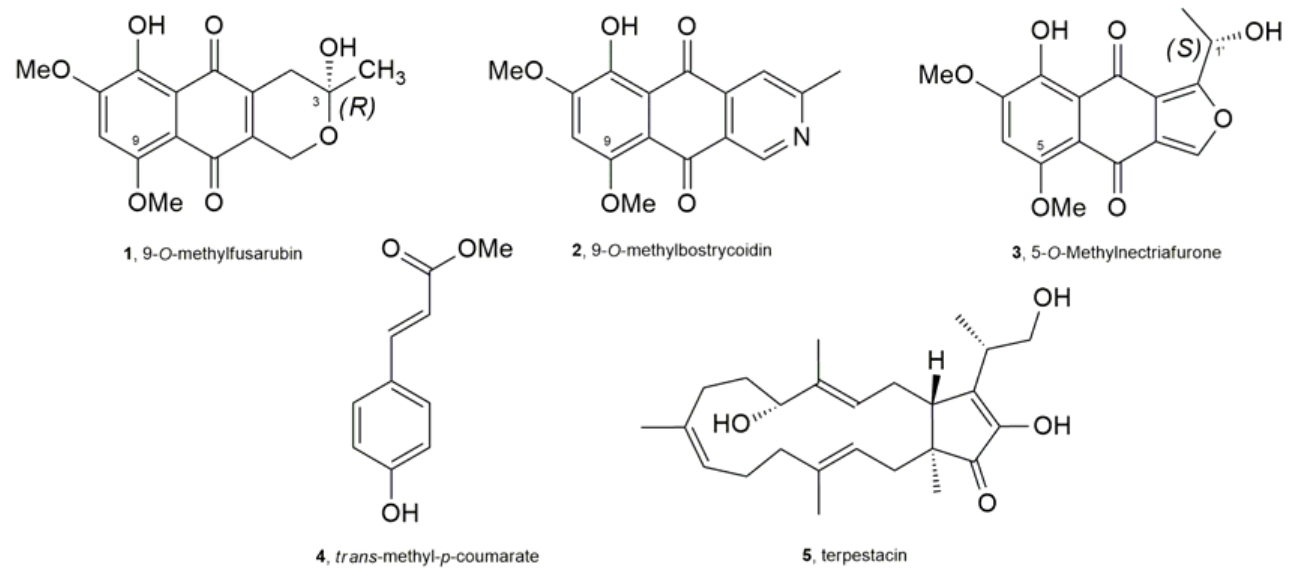

Figure 2. Structures of compounds 1-5. 
Their identification was carried out using extensive spectroscopic, optical and computational methods. In particular, the preliminary ${ }^{1} \mathrm{H}$ - and ${ }^{13} \mathrm{C}-\mathrm{NMR}$ investigation of the main metabolite, obtained as an amorphous red solid, showed the typical signal systems of a polysubstituted naphthoquinone $[23,24]$. They also appeared to be were very similar to those reported in literature for 9-O-methylfusarubin (1, Figure 2) [14,15]. This result was also confirmed by HRESIMS, recorded in positive modality, which showed the protonated form $[\mathrm{M}+\mathrm{H}]^{+}$at $\mathrm{m} / z 321.0979$ consistent with a molecular formula of $\mathrm{C}_{16} \mathrm{H}_{16} \mathrm{O}_{7}$. This metabolite was isolated for the first time from Fusarium moniliforme in 1979 [16] and successively from other different Fusarium spp. [14,15,25,26], from the endolichenic fungus Corynespora sp. BA-10763 [27], and from the sea hare associated fungus Torula herbarum [28]. It was also called 8-O-methylfusarubin [15], but, in this paper, the name 9-O-methylfusarubin is adopted in agreement with IUPAC carbon skeleton numbering. Furthermore, to the best of our knowledge, the absolute configuration (AC) at C-3 of $\mathbf{1}$ has not been previously determined. Considering that the absolute configuration of natural products is often closely related to their biological activity [10], the AC of $\mathbf{1}$ and $\mathbf{3}$ was determined using different methods as following.

The AC of compound 1 was established by quantum-chemical calculations of ECD and VCD spectra, using a consolidated protocol [29,30]. Briefly, the molecular structure was investigated by means of a conformational search with Merck Molecular Force Field (MMFF) and geometry optimizations with density functional theory (DFT) at the $\omega B 97 X-D / 6-311+G(d, p)$, including a continuum solvent model (PCM) for MeCN or MeOH. Only three low-energy minima were detected, the most stable of which (see inset in Figure 3) accounted for $>93 \%$ population at $300 \mathrm{~K}$ according to internal energies.

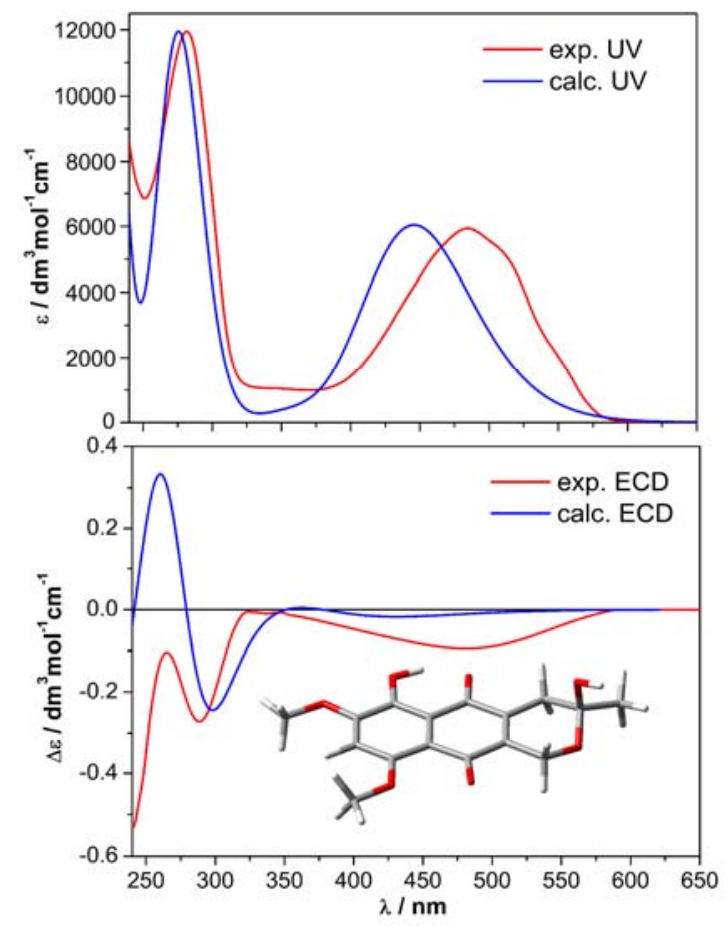

Figure 3. Comparison of experimental and calculated UV/ECD spectra for $(R)-1$. Measurement run on $0.25 \mathrm{mM}$ solution in MeCN. Calculations run at CAM-B3LYP/def2-TZVP// $\omega B$ B7X-D/6-311+G(d,p) level including a PCM solvent model for MeCN; Boltzmann averaged over three conformers (the most stable is shown in the inset); plotted as sum of Gaussian function with $0.5 \mathrm{eV}$ exponential band-width, red-shifted by $21 \mathrm{~nm}$ and scaled by a factor 9.835 .

Time-dependent DFT calculations (TDDFT) were run with various combinations of functionals and basis sets; the results obtained with CAM-B3LYP/def2-TZVP/PCM are discussed here. 
Additionally, frequency calculations were run at the $\omega$ B97X-D/6-311+G(d,p)/PCM level. Figures 3 and 4 show, respectively, the experimental and calculated UV/ECD and IR/VCD spectra for the $(3 R)$ enantiomer of $\mathbf{1}$. Neither ECD nor VCD spectra were perfectly reproduced over the whole available range; however, the agreement was in both cases sufficient and consistent. The similarity factors $[21,22]$ were estimated as 0.57 for $(R)$ enantiomer and 0.037 for the $(S)$ enantiomers by VCD. The use of two chiroptical techniques, whose conclusions reinforce each other, is especially important when dealing with weak ECD or VCD spectra, as in the current and similar cases [30,31]. Thus, the absolute configuration of 9-O-methylfusarubin is assigned as $(R)-\mathbf{1}$. The consistency between experimental and calculated $g$-factors $(\Delta \varepsilon / \varepsilon)$ in the VCD/IR spectra indicates the enantiomeric purity of the natural product 1 .

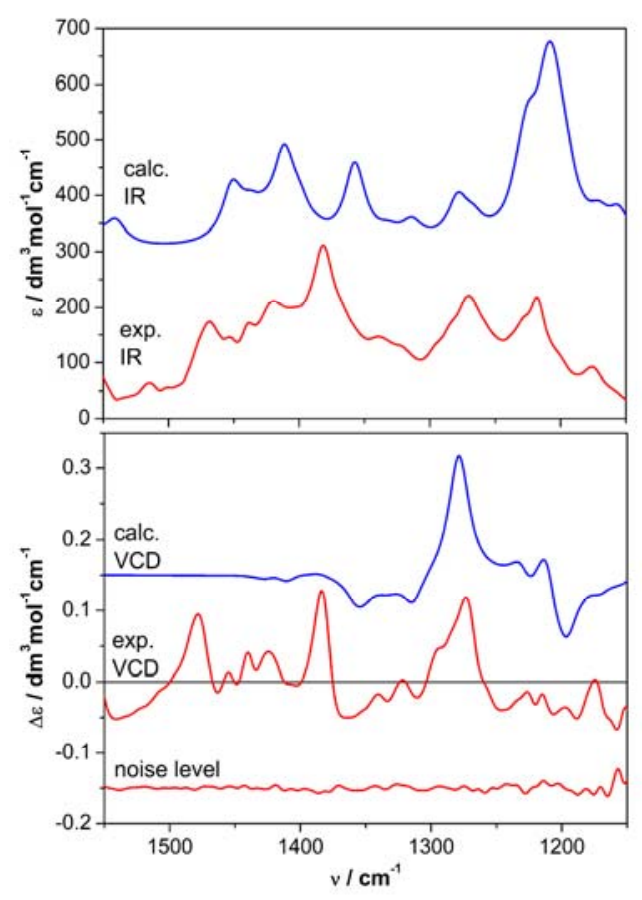

Figure 4. Comparison of experimental and calculated IR/VCD spectra for $(R)-\mathbf{1}$. Measurement run on $16 \mathrm{mM}$ solution in $\mathrm{CD}_{3} \mathrm{OD}, 100 \mu \mathrm{m} \mathrm{BaF} 2$ cell. Calculations run at $\omega \mathrm{B} 97 \mathrm{X}-\mathrm{D} / 6-311+\mathrm{G}(\mathrm{d}, \mathrm{p})$ level including PCM solvent model for $\mathrm{MeOH}$; Boltzmann averaged over three conformers; plotted as sum of Lorentzian functions with $10 \mathrm{~cm}^{-1}$ half-width at full maximum and frequency scale factor 0.948 .

9-O-methylfusarubin (1) showed bactericidal activity against some Gram+ bacteria while it was inactive when tested against Gram- bacteria [25,32]. Other biological activities, namely phytotoxic and chlorotic-inducing properties in plants as well as its potential as an anticancer agent, were evaluated when it was isolated from Fusarium oxysporum. It showed phytotoxic activity against wheat, bean, corn and tobacco plants at different concentrations and antineoplastic effects on ras transformed liver epithelial cells [26]. Finally, compound 1 inhibited hepatic glucose production at an $\mathrm{IC}_{50}$ value of $4.8 \mu \mathrm{M}$ and showed cytotoxicity against hepatic cells after incubation for $48 \mathrm{~h}$ [33].

Compound 2 was identified as the known metabolite 9-O-methylbostrycoidin by comparing its ${ }^{1} \mathrm{H}$ - and ${ }^{13} \mathrm{C}-\mathrm{NMR}$ spectra with those reported in literature when it was isolated from some species of Fusarium $[14,16]$. Its HRESIMS, recorded in positive modality, showed the protonated form $[\mathrm{M}+\mathrm{H}]^{+}$ at $m / z 300.0880$ consistent with a molecular formula of $\mathrm{C}_{16} \mathrm{H}_{13} \mathrm{NO}_{5}$. 9-O-methylbostrycoidin was also isolated from the liquid cultures of the mangrove endophytic fungus Aspergillus terreus (No. GX7-3B) [34] and of the endolichenic fungus Corynespora sp. BA-10763 [27]. In addition, 2 displayed remarkable inhibiting action against $\alpha$-acetylcholinesterase (AChE) with an $\mathrm{IC}_{50}$ value of $6.71 \mu \mathrm{M}$ [34], inhibited hepatic glucose production at an $\mathrm{IC}_{50}$ value of $30 \mu \mathrm{M}$, and showed weak cytotoxicity against 
hepatic cells after incubation for 48h [33]. It also showed bactericidal activity against some Gram+ bacteria, but it has never been tested for phytotoxic activity.

Compound 3 showed ${ }^{1} \mathrm{H}$ - and ${ }^{13} \mathrm{C}-\mathrm{NMR}$ data very similar to those previously reported in literature for the 5-O-methylnectriafurone [14,17]. This identification was supported by the data of its HRESIMS, which showed the protonated form $[\mathrm{M}+\mathrm{H}]^{+}$at $m / z 319.0803$ consistent with a molecular formula of $\mathrm{C}_{16} \mathrm{H}_{14} \mathrm{O}_{7}$. This compound was only produced by $F$. oxysporum obtained from roots of diseased citrus trees [17] and by a strain of Fusarium proliferatum, an endophytic fungus isolated from Syzygium cordatum [14]. No biological activities were reported and its AC was not determined. Thus, the AC of 3 was determined applying the advanced Mosher's method [19] appropriately derivatizing the chiral secondary alcohol at $\mathrm{C}-1^{\prime}$. In particular, 5-O-methylnectriafurone (3) by reaction with $R$-(-)- $\alpha$-methoxy- $\alpha$-trifluoromethylphenylacetyl (MTPA) and S-(+)-MTPA chlorides, was converted into the corresponding diastereomeric esters at $C-1^{\prime}(6,7)$. Subtracting the proton chemical shifts (Table 1) of the $1^{\prime}-O-R$-MTPA (7) from those of $1^{\prime}-O-S$-MTPA (6) esters, the $\Delta \delta(6-7)$ values for all of the protons were determined as reported in Figure 5 . The positive $\Delta \delta$ values were located on the right side, and those with negative values on the left side of model A as reported in Cimmino et al. [35]. This model allowed the assignment of the $S$ configuration at $C-1^{\prime}$. The appearance of single set of signals for both 6 and 7 indicates the enantiomeric purity of the natural product 3.

Table 1. ${ }^{1} \mathrm{H}-\mathrm{NMR}$ data of 6 and 7 recoded in $\mathrm{CDCl}_{3}$ a.

\begin{tabular}{ccc}
\hline & 6 & 7 \\
\hline Position & $\delta_{\mathrm{H}}(\mathrm{J} \mathrm{in} \mathrm{Hz})$ & $\delta_{\mathrm{H}}(J$ in Hz$)$ \\
3 & $8.062(1 \mathrm{H}, \mathrm{s})$ & $7.998(1 \mathrm{H}, \mathrm{s})$ \\
$\mathrm{MeO}-5^{\mathrm{b}}$ & $4.042(3 \mathrm{H}, \mathrm{s})$ & $4.041(3 \mathrm{H}, \mathrm{s})$ \\
6 & $6.833(1 \mathrm{H}, \mathrm{s})$ & $6.827(1 \mathrm{H}, \mathrm{s})$ \\
$\mathrm{MeO}-7^{\mathrm{b}}$ & $4.014(3 \mathrm{H}, \mathrm{s})$ & $4.012(3 \mathrm{H}, \mathrm{s})$ \\
$1^{\prime}$ & $5.976(1 \mathrm{H}, \mathrm{q}, J=8.0)$ & $5.824(1 \mathrm{H}, \mathrm{q}, J=8.0)$ \\
$2^{\prime}$ & $1.717(3 \mathrm{H}, \mathrm{d}, J=8.0)$ & $1.786(3 \mathrm{H}, \mathrm{d}, J=8.0)$ \\
$\mathrm{MeO}$ & $3.580(3 \mathrm{H}, \mathrm{s})$ & $3.569(3 \mathrm{H}, \mathrm{s})$ \\
$\mathrm{Ph}$ & $7.505-7.380(5 \mathrm{H}, \mathrm{m})$ & $7.491-7.367(5 \mathrm{H}, \mathrm{m})$ \\
$\mathrm{OH}-8$ & $13.481(\mathrm{br} \mathrm{s})$ & $13.480(\mathrm{br} \mathrm{s})$ \\
\hline
\end{tabular}

${ }^{a}$ The chemical shifts are in $\delta$ values (ppm) from TMS. ${ }^{b}$ These signals could be exchangeable.

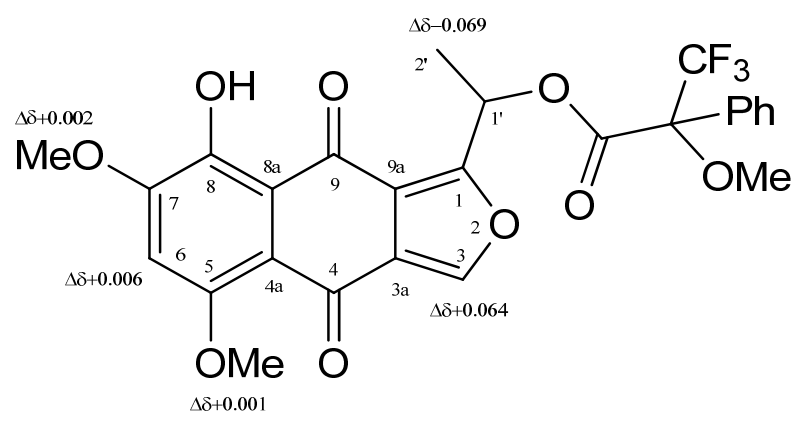

Figure 5. Structures of $1^{\prime}-O-S$ - and 1'-O-R-MTPA of 3 (6 and 7, respectively), reporting the $\Delta \delta$ values obtained by comparison of each proton system.

On the basis of these findings, 5-O-methylnectriafurone was formulated as (1'S)-1-(1hydroxyethyl)-5,7,8-trimethoxynaphtho[2,3-c]furan-4,9-dione (3).

Compound 4 was identified as the methyl ester of $p$-coumaric acid by comparing its ${ }^{1} \mathrm{H}$ - and ${ }^{13} \mathrm{C}-\mathrm{NMR}$ data with those reported in the literature [18] and confirmed by its HRESIMS which showed the protonated form $[\mathrm{M}+\mathrm{H}]^{+}$at $m / z 179.0711$ consistent with a molecular formula of $\mathrm{C}_{10} \mathrm{H}_{10} \mathrm{O}_{3}$. 
Compound 4 is a well-known plant metabolite with diverse biological activity that has rarely been reported as a fungal metabolite [36]. However, phytotoxic activity was reported only against the green alga Selenastrum capricornutum when compound 4 was isolated from the aquatic plant Schoenoplectus lacustris [37].

Compound 5 showed ${ }^{1} \mathrm{H}$ - and ${ }^{13} \mathrm{C}-\mathrm{NMR}$ data very similar to those reported in the literature for terpestacin [19]. Furthermore, the measured optical rotation value is coincident with the previously reported one, indicating the enantiomeric purity of the natural product 5 [19]. Its identification was supported by the data of the HRESIMS, which showed the sodium cluster $[\mathrm{M}+\mathrm{Na}]^{+}$at $m / z 425.2743$ consistent with a molecular formula of $\mathrm{C}_{25} \mathrm{H}_{38} \mathrm{O}_{4}$. Terpestacin (5) is a well-known mycotoxin that was first isolated in 1993 from Arthrinium sp. FA 1744 (ATCC 74132) and showed syncytium formation inhibitory activity [38]. Moreover 5, together with its analogue fusaproliferin, was recently isolated from a mangrove-derived endophytic fungus F. proliferatum MA-84 [39] and from the fimicolous fungi Cleistothelebolus nipigonensis and Neogymnomyces virgineus [19]. Furthermore, some key hemisynthetic derivatives were prepared starting form terpestacin and fusaproliferin and their antifungal activity was tested against some Ascomycetous fungi. In particular, these metabolites and their derivatives reduced the growth of Alternaria brassicicola, Botrytis cinerea and Fusarium graminearum, demonstrating their allelopathic activity [19].

The five pure compounds were tested for toxicity against B. tectorum using a radicle/coleoptile elongation test and a juvenile plant immersion test at $10^{-4} \mathrm{M}$ as described in the Experimental section. None of the compounds slowed or prevented seed germination or had a negative effect on 5-day post-germination length of either the radicle or the coleoptile relative to the control treatment (data not shown). In the juvenile plant immersion test (Figure 6), 9-O-methyl-fusarubin and terpestacin showed significant phytotoxic effects relative to the control. With these two compounds, most juvenile plants suffered complete wilting, discoloration, and death within 10 days as illustrated in Figure 1. Both metabolites have potential as natural herbicides. However, before planning their practical application, it is important to investigate their persistence in soil and water and toxicity of their degraded compounds.

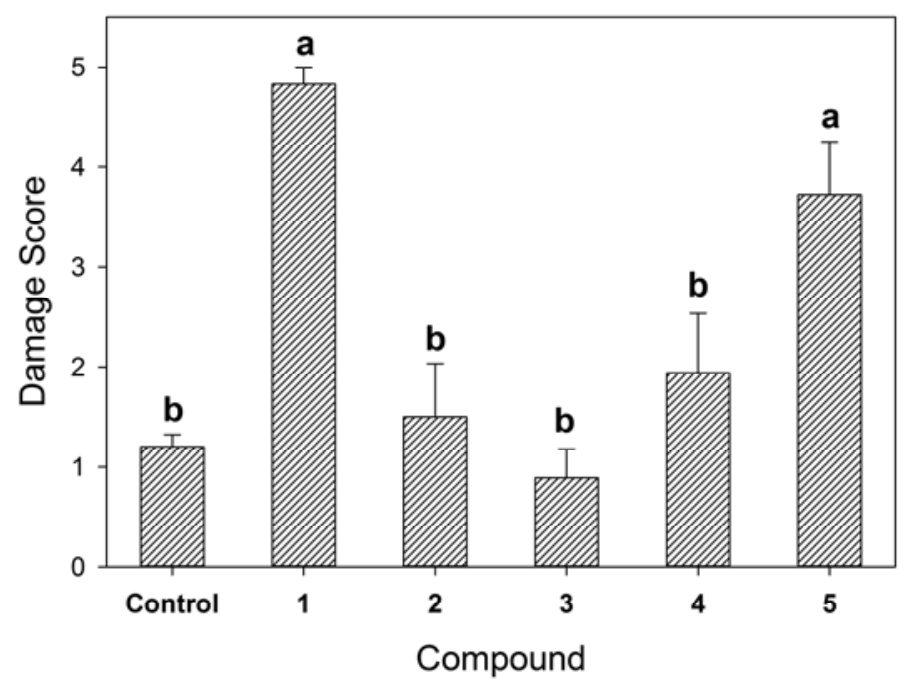

Figure 6. Effect of five pure compounds obtained from R. capillus-albis solid culture on juvenile plants of $B$. tectorum when tested at $10^{-4} \mathrm{M}$ in a juvenile plant immersion bioassay against a methanol solvent control. Symptoms were scored at 10 days on an approximately linear scale from 0 (no visible damage) to 5 (complete mortality). Bars headed by the same letter ( $a$ or $b$ ) are not significantly different at $p<0.05$ according to a means separation test from analysis of variance. 


\section{Conclusions}

This paper reports the isolation and identification 9-O-methylfusarubin, 9-O-methylbostrycoidin, 5-O-methylnectriafurone, trans-methyl- $p$-coumarate and terpestacin produced as secondary metabolites by the newly described plant pathogen $R$. capillus-albis, as well as their phytotoxic activity against $B$. tectorum. The absolute configuration at C-3 of 9-O-methylfusarubin and at C-1' of 5-O-methylnectriafurone were also determined for the first time by applying electronic circular dichroism (ECD), vibrational CD (VCD), computational methods, and the advanced Mosher's method, respectively. The results obtained with 9-O-methylfusarubin and terpestacin in a juvenile plant immersion bioassay suggest that these two compounds could play a role in pathogenesis on B. tectorum. However, there may be additional roles for these compounds beyond those investigated in this study. Compounds 1-3 could be responsible for the coloration of the fungal stromata as already demonstrated for the fruiting bodies in Fusarium fujikuroi [40]. In fact, they have not been detected in liquid PDB culture of R. capillus-albis (Masi et al. unpublished data), supporting this idea. Furthermore, these naphthoquinones could be protectants against harmful environmental conditions such as UV irradiation, reactive oxygen species (ROS) and desiccation [40,41] or help the fungus in defense against its natural enemies. The results of the bioassays and these last considerations could increase the potential of R. capillus-albis to control cheatgrass. Finally, considering several biological properties showed by natural anthraquinones [42], future studies will be performed to evaluate the potential practical application of these compounds in different fields. In particular, it will be interesting to speculate on their industrial applications as natural dyes to replace synthetic chemicals in formulation in order to prevent negative environmental effects [42].

Supplementary Materials: A fractionation scheme (Scheme S1) of the fungal metabolites $\mathbf{1 - 5}$ and their ${ }^{1} \mathrm{H}-\mathrm{NMR}$ spectra are reported in the Supplementary Materials available online.

Author Contributions: M.M. performed the research, recorded the spectra and wrote a draft of the manuscript; S.C. performed the bioassays and S.M. analyzed the data; M.G. and G.P. performed the study on the absolute configuration determination and wrote the relative parts in the manuscript; A.C., A.E. and S.M. finalized the draft and revised the manuscript. All authors read and approved the final manuscript

Funding: This research was funded by Programme STAR 2017, financially supported by UniNA and Compagnia di San Paolo grant number E62F16001250003."

Acknowledgments: This work was funded in part through a grant to SEM in 2011 from the US Department of the Interior Bureau of Land Management Integrated Cheatgrass Die-off Project. The authors thank Çigdem Karakoyun for her technical contribution to this work. Antonio Evidente is associated with "Istituto di Chimica Biomolecolare del CNR", Pozzuoli, Italy. M.G. is thankful for the support from the Polish Ministry of Science and Higher Education ('Mobilnosc Plus' Grant No. 1286/MOB/IV/2015/0). All computational calculations were performed at Wroclaw Centre for Networking and Supercomputing (WCSS) in Poland.

Conflicts of Interest: The authors declare no conflict of interest.

\section{References}

1. Brooks, M.L.; D'Antonio, C.M.; Richardson, D.M.; Grace, J.B.; Keeley, J.E.; DiTomaso, J.M.; Hobbs, R.J.; Pellant, M.; Pyke, D. Effects of invasive alien plants on fire regimes. BioScience 2004, 54, 677-688. [CrossRef]

2. Chambers, J.C.; Bradley, B.A.; Brown, C.S.; D’Antonio, C.; Germino, M.J.; Grace, J.B.; Hardegree, S.P.; Miller, R.F.; Pyke, D.A. Resilience to stress and disturbance, and resistance to Bromus tectorum L. invasion in cold desert shrublands of western North America. Ecosystems 2014, 17, 360-375. [CrossRef]

3. Meyer, S.E.; Beckstead, J.; Pearce, J. Community ecology of fungal pathogens on Bromus tectorum, Chapter 7. In Exotic Brome-Grasses in Arid and Semiarid Ecosystems of the Western US; Springer International Publishing: New York, NY, USA, 2016; pp. 193-223.

4. Baughman, O.W.; Meyer, S.E. Is Pyrenophora semeniperda the cause of downy brome (Bromus tectorum) die-offs? Invasive Plant Sci. Manag. 2013, 6, 105-111. [CrossRef]

5. Meyer, S.E.; Masi, M.; Clement, S.; Davis, T.L.; Beckstead, J. Mycelial growth rate and toxin production in the seed pathogen Pyrenophora semeniperda: Resource trade-offs and temporally varying selection. Plant Pathol. 2015, 64, 1450-1460. [CrossRef] 
6. Masi, M.; Evidente, A.; Meyer, S.; Nicholson, J.; Muñoz, A. Effect of strain and cultural conditions on the production of cytochalasin B by the potential mycoherbicide Pyrenophora semeniperda (Pleosporaceae, Pleosporales). Biocontrol Sci. Technol. 2014, 24, 53-64. [CrossRef]

7. Masi, M.; Meyer, S.; Cimmino, A.; Andolfi, A.; Evidente, A. Pyrenophoric acid, a phytotoxic sesquiterpenoid penta-2,4-dienoic acid produced by a potential mycoherbicide. Pyrenophora semeniperda. J. Nat. Prod. 2014, 77, 925-930. [CrossRef] [PubMed]

8. Masi, M.; Meyer, S.; Cimmino, A.; Clement, S.; Black, B.; Evidente, A. Pyrenophoric acids B. and C., two new phytotoxic sesquiterpenoids produced by Pyrenophora semeniperda. J. Nat. Prod. 2014, 62, 10304-10311. [CrossRef] [PubMed]

9. Masi, M.; Meyer, S.; Clement, S.; Andolfi, A.; Cimmino, A.; Evidente, A. Spirostaphylotrichin W, a spirocyclic $\gamma$-lactam isolated from liquid culture of Pyrenophora semeniperda, a potential mycoherbicide for cheatgrass (Bromus tectorum) biocontrol. Tetrahedron 2014, 70, 1497-1501. [CrossRef]

10. Cimmino, A.; Masi, M.; Evidente, M.; Superchi, S.; Evidente, A. Fungal phytotoxins with potential herbicidal activity: Chemical and biological characterization. Nat. Prod. Rep. 2015, 32, 1629-1653. [CrossRef] [PubMed]

11. Masi, M.; Meyer, S.; Pescitelli, G.; Cimmino, A.; Clement, S.; Peacock, B.; Evidente, A. Phytotoxic activity against Bromus tectorum for secondary metabolites of a seed-pathogenic Fusarium strain belonging to the F. tricinctum species complex. Nat. Prod. Res. 2017, 31, 2768-2777. [CrossRef] [PubMed]

12. Pearce, J.F.; Meyer, S.E.; Geary, B.D.; Ricks, N.; Coleman, C.E. The fungal pathogen Rutstroemia capillus-albis sp.n. is the causal agent of bleach blonde syndrome on Bromus tectorum. Mycologia in review.

13. Berger, S.; Braun, S. 200 and More Basic NMR Experiments: A Practical Course, 3rd ed.; Wiley-VCH: Weinheim, Germany, 2004.

14. Dame, Z.T.; Silima, B.; Gryzenhout, M.; van Ree, T. Bioactive compounds from the endophytic fungus Fusarium proliferatum. Nat. Prod. Res. 2016, 30, 1301-1304. [CrossRef] [PubMed]

15. Gopalakrishnan, S.; Beale, M.H.; Ward, J.L.; Strange, R.N. Chickpea wilt: Identification and toxicity of 8-O-methylfusarubin from Fusarium acutatum. Phytochemistry 2005, 66, 1536-1539. [CrossRef] [PubMed]

16. Steyn, P.S.; Wessels, P.L.; Marasas, W.F. Pigments from Fusarium moniliforme sheldon: Structure and ${ }^{13} \mathrm{C}$ nuclear magnetic resonance assignments of an azaanthraquinone and three naphthoquinones. Tetrahedron 1979, 35, 1551-1555. [CrossRef]

17. Tatum, J.H.; Baker, R.A.; Berry, R.E. Naphthofurans produced by Fusarium oxysporum isolated from citrus. Phytochemistry 1987, 26, 2499-2500. [CrossRef]

18. Chen, C.Y.; Chang, F.R.; Teng, C.M.; Wu, Y.C. Cheritamine, a new N-fatty acyl tryptamine and other constituents from the stems of Annona cherimola. J. Chin. Chem. Soc. 1999, 46, 77-86. [CrossRef]

19. Cimmino, A.; Sarrocco, S.; Masi, M.; Diquattro, S.; Evidente, M.; Vannacci, G.; Evidente, A. Fusaproliferin, terpestacin and their derivatives display variable allelopathic activity against some ascomycetous fungi. Chem. Biodivers. 2016, 13, 1593-1600. [CrossRef] [PubMed]

20. Frisch, M.J.; Trucks, G.W.; Schlegel, H.B.; Scuseria, G.E.; Robb, M.A.; Cheeseman, J.R.; Scalmani, G.; Barone, V.; Petersson, G.A.; Nakatsuji, H.; et al. Gaussian 16, Revision, A.03; Gaussian Inc.: Wallingford, CT, USA, 2016.

21. Bruhn, T.; Schaumloeffel, A.; Hemberger, Y.; Bringmann, G. SpecDis: Quantifying the comparison of calculated and experimental electronic circular dichroism spectra. Chirality 2013, 25, 243-249. [CrossRef] [PubMed]

22. Bruhn, T.; Schaumlöffel, A.; Hemberger, Y.; Pescitelli, G. SpecDis, version 1.71; Berlin, Germany, 2017. Available online: https:/ / specdis-software.jimdo.com/ (accessed on 20 June 2018).

23. Pretsch, E.; Buhlmann, P.; Badertscher, M. Structure Determination of Organic Compounds-Tables of Spectral Data, 4th ed.; Springer-Verlag: Berlin, Germany, 2009.

24. Breitmaier, E.; Voelter, W. Carbon-13 NMR Spectroscopy; VCH Verlagsgesellschaft: Weinheim, Germany, 1987; pp. 183-280.

25. Visconti, A.; Surico, G.; Iacobellis, N.S.; Bottalico, A. Production of pigments by isolates of Fusarium moniliforme Sheld. from cereals in Italy and their antibacterial acitivity. Phytopathol. Mediterr. 1983, 22, 152-156.

26. Bauer, J.D.; Cutler, H.G.; Hugdahl, J.D.; Garcia, E.L.; Matesic, D.F.; Cutler, S.J. Biological evaluation of a secondary metabolite, 9-O-methylfusarubin, from Fusarium oxysporum. Med. Chem. Res. 2005, 14, 369-381. [CrossRef] 
27. Wijeratne, E.K.; Bashyal, B.P.; Gunatilaka, M.K.; Arnold, A.E.; Gunatilaka, A.L. Maximizing chemical diversity of fungal metabolites: Biogenetically related heptaketides of the endolichenic fungus Corynespora sp. (1). J. Nat. Prod. 2010, 73, 1156-1159. [CrossRef] [PubMed]

28. Geng, W.L.; Wang, X.Y.; Kurtán, T.; Mándi, A.; Tang, H.; Schulz, B.; Sung, P.; Zhang, W. Herbarone, a rearranged heptaketide derivative from the sea hare associated fungus Torula herbarum. J. Nat. Prod. 2012, 75, 1828-1832. [CrossRef] [PubMed]

29. Pescitelli, G.; Bruhn, T. Good computational practice in the assignment of absolute configurations by TDDFT calculations of ECD spectra. Chirality 2016, 28, 466-474. [CrossRef] [PubMed]

30. Superchi, S.; Scafato, P.; Górecki, M.; Pescitelli, G. Absolute configuration determination by quantum mechanical calculation of chiroptical spectra: Basics and applications to fungal metabolites. Curr. Med. Chem. 2018, 25, 287-320. [CrossRef] [PubMed]

31. Rossi, D.; Mahmood Ahmed, K.; Gaggeri, R.; Della Volpe, S.; Maggi, L.; Mazzeo, G.; Longhi, G.; Abbate, S.; Corana, F.; Martino, E.; et al. (R)-(-)-Aloesaponol III 8-methyl ether from Eremurus persicus: A novel compound against leishmaniosis. Molecules 2017, 22, 519-534. [CrossRef] [PubMed]

32. Baker, R.A.; Tatum, J.H.; Nemec, S. Antimicrobial activity of naphthoquinones from Fusaria. Mycopathologia 1990, 111, 9-15. [CrossRef] [PubMed]

33. Hashimoto, J.; Motohashi, K.; Sakamoto, K.; Hashimoto, S.; Yamanouchi, M.; Tanaka, H.; Takahashi, T.; Takagi, M.; Shin-ya, K. Screening and evaluation of new inhibitors of hepatic glucose production. J. Antibiot. 2009, 62, 625-629. [CrossRef] [PubMed]

34. Deng, C.M.; Liu, S.X.; Huang, C.H.; Pang, J.Y.; Lin, Y.C. Secondary metabolites of a mangrove endophytic fungus Aspergillus terreus (No. GX7-3B) from the South China Sea. Mar. Drugs 2013, 11, 2616-2624. [CrossRef] [PubMed]

35. Cimmino, A.; Masi, M.; Evidente, M.; Superchi, S.; Evidente, A. Application of Mosher's method for absolute configuration assignment to bioactive plants and fungi metabolites. J. Pharm. Biomed. Anal. 2017, 144, 59-89. [CrossRef] [PubMed]

36. Dewick, P.M. Medicinal Natural Products: A Biosynthetic Approach, 3th ed.; John Wiley \& Sons: Chichester, UK, 2009.

37. D'Abrosca, B.; Dellagreca, M.; Fiorentino, A.; Isidori, M.; Monaco, P.; Pacifico, S. Chemical constituents of the aquatic plant Schoenoplectus lacustris: Evaluation of phytotoxic effects on the green alga Selenastrum capricornutum. J. Chem. Ecol. 2006, 32, 81-96. [CrossRef] [PubMed]

38. Oka, M.; Iimura, S.; Narita, Y.; Furumai, T.; Konishi, M.; Oki, T.; Gao, Q.; Kakisawa, H. Stereochemistry and biosynthesis of terpestacin, a new syncytium formation inhibitor. J. Org. Chem. 1993, 58, 1875-1881. [CrossRef]

39. Liu, D.; Li, X.M.; Li, C.S.; Wang, B.G. Sesterterpenes and $2 H$-pyran-2-ones (= $\alpha$-pyrones) from the mangrove-derived endophytic fungus Fusarium proliferatum MA-84. Helv. Chim. Acta 2013, 96, 437-444. [CrossRef]

40. Graziani, S.; Vasnier, C.; Daboussi, M.J. Novel polyketide synthase from Nectria haematococca. Appl. Environ. Microbiol. 2004, 70, 2984-2988. [CrossRef] [PubMed]

41. Studt, L.; Wiemann, P.; Kleigrewe, K.; Humpf, H.U.; Tudzynski, B. Biosynthesis of fusarubins accounts for pigmentation of Fusarium fujikuroi perithecia. Appl. Environ. Microbiol. 2012, 78, 4468-4480. [CrossRef] [PubMed]

42. Duval, J.; Pecher, V.; Poujol, M.; Lesellier, E. Research advances for the extraction, analysis and uses of anthraquinones: A. review. Ind. Crops Prod. 2016, 94, 812-833. [CrossRef]

Sample Availability: Samples of the compounds 1-5 are available from the authors. 